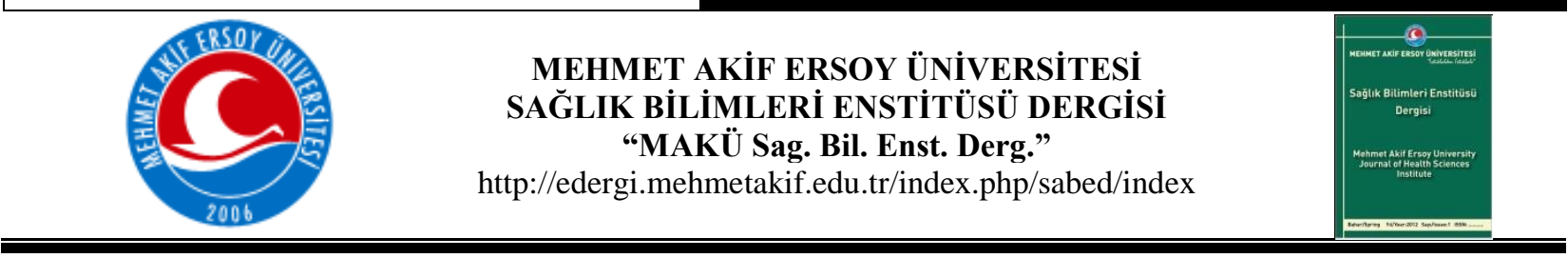

\title{
Adipoz Doku ve Adipoz Dokudan Salınan Bazı Proteinler
}

\author{
Adipose Tissue and Some Proteins Released from Adipose Tissue \\ Şule Demirci ${ }^{1}$, Cennet Gün ${ }^{2}$ \\ ${ }^{1}$ Mehmet Akif Ersoy Üniversitesi, Veteriner Fakültesi, Fizyoloji Anabilim Dal, BURDUR, TÜRKIYYE \\ ${ }^{2}$ Mehmet Akif Ersoy Üniversitesi, Sağlık Bilimleri Enstitüsü, BURDUR, TÜRKIYYE
}

\begin{abstract}
Obesity is very common in developed and developing countries as a result of inactivity and a diet with excess fat foods due to changes in the conditions of life. Studies have shown that obesity is actually a low-level chronic inflammation of adipose tissue and it has been revealed that this condition of adipose tissue contributes to obesity-related systemic metabolic dysfunctions.

Adipokines secreted from adipose tissue are bioactive substances which have metabolic and/or pro/anti-inflammatory effects. The disorder of the production or secretion of these adipokines due to adipose tissue dysfunction in obesity causes complications of many diseases, decreasing the quality of living conditions and increasing the mortality rate. In this review, it is aimed to give information about different adipose tissue structures, functions varying according to structures, and some adipokines secreted from the adipose tissue which has the pro / anti-inflammatory and energy-balanced effects.
\end{abstract}

Key words: Adipose tissue, adipokine, cytokine, obesity

Yazıșma Adresi: Prof.Dr. Şule Demirci Mehmet Akif Ersoy Üniversitesi, Veteriner Fakültesi, Fizyoloji Anabilim Dalı, BURDUR, TÜRKIYE E-posta: suledemirci67@hotmail.com

Tel: +9002482132110

Kaynak göstermek için: Demirci Ş, Gün C. 2017. Adipoz Doku ve Adipoz Dokudan Salınan Bazı Proteinler. MAKÜ Sag. Bil. Enst. Derg. 5(2): 155-179.

\begin{abstract}
Öz: Gelişmiş ve gelişmekte olan ülkelerde yaşam şartlarının değişmesi nedeniyle hareketsizlik ve aşırı yağlı gıdalarla beslenme sonucu obezite yaygın olarak görülmektedir. Yapılan çalışmalarda obezitenin aslında düşük seviyede seyreden kronik bir adipoz doku yangısı olduğu ve bu durumun obezite ilişkili sistemik metabolik fonksiyon bozukluklarına katkıda bulunduğu ortaya konmuştur.

Adipoz dokudan salgılanan adipokinler, metabolik ve/veya pro/antiinflamatuar etkilere sahip olan biyoaktif maddelerdir. Obezitedeki adipoz doku disfonksiyonu nedeniyle bu adipokinlerin yapımı veya salgılanmasının düzensizliği birçok hastalık komplikasyonları oluşturmakta, yaşam koşullarının kalitesinin azalmasına ve mortalite oranının artmasına neden olmaktadır. $\mathrm{Bu}$ derlemede, farklı adipoz doku yapıları, yapılarına göre değişen fonksiyonları ve adipoz dokudan salgılanan pro/anti-inflamatuar ve enerji dengesinde etkili adipokinlerden bazıları hakkında bilgi verilmesi amaçlanmıştır.
\end{abstract}

Anahtar sözcükler: Adipoz doku, adipokin, sitokin, obezite

Geliş Tarihi: 13.09.2017～Kabul Tarihi: 27.11.2017 


\section{Giriş}

Obezitenin dünya çapında yaygınlaşması; obeziteye bağlı bazı metabolik hastalıklar (Tip 2 diyabet, yağlı karaciğer sendromu ve dislipidemi), kardiyovasküler hastalıklar (hipertansiyon, koroner kalp hastalığı, felç), merkezi sinir sistemi hastalıkları (demans), obstrüktif uyku apnesi ve değişik tip kanserlerin oluşmasında risk faktörü olması (Blüher ve Mantzoros, 2015, LeRoith ve ark. 2008, Van Gaal ve ark. 2006), yağ hücrelerinin biyolojisini anlama ile obezlerdeki adipoz dokuda ve diğer metabolik faaliyetlerde meydana gelen değişimlerin anlaşılmasına yönelik araştırmaların artmasına neden olmuştur.

\section{Adipoz Doku Gelişimi ve Çeşitleri}

Yaşayan organizmalar canlı kalabilmek için çevrelerinden enerji almaya ihtiyaç duyarlar. Özellikle gıda alımı fazla olduğunda enerjinin fazlasının depolanması, gıda alınamadığı zamanlarda hayatta kalmayı artırıcı önemli fizyolojik bir aktivitedir. Çok hücreli organizmalar, fazla enerji kaynağı alındığında lipidleri depolamak için özelleşmiş hücre ya da organlara sahiptirler. Bazı balıklar ve memelilerde ise enerji rezervuarı olarak, glikozdan yağ asidi sentezlendeği veya lipoproteinler ile taşınan yağların depolandığı adipoz doku görev almaktadır (Birsoy ve ark. 2013).

Adipoz doku hücre sayısı ve büyüklüğü bakımından enerji ihtiyacı ve tüketimine bağlı olarak, yaşam boyu sürekli hacim değişkenliği gösteren bir dokudur. Adipoz doku salgıladığı enzim, sitokin, büyüme faktörü ve hormonlarla biyolojik fonksiyonlar ve özellikle enerji metabolizmasının düzenlenmesinde çok önemli bir yere sahiptir.

Adipoz doku enerjinin depo edildiği bir doku olmakla birlikte, endokrin bir yapı gibi metabolik dengeyi etkileyen biyolojik olarak aktif birçok maddeyi sentezleme kapasitesi nedeni ile metabolik anlamda dinamik bir organ olarak görülmektedir (Coelho ve ark. 2013). Adipoz doku, genellikle yağ doku olarak adlandırılır ve esasen içerisinde mesodermal orijinli multipotent kök hücrelerinden köken almış; adiposit, kondrosit, osteoblast veya miyositlere dönüşebilme kapasitesinde olan preadipositler (Gregoire ve ark. 1998) lipidle dolu adipositler, fibroblastlar, immun hücreler, kan damarları ve kollajen liflerin oluşturduğu bir matriks tarafından çevrilmiş bir gevşek bağ doku tipidir (Ahima ve Flier, 2000). 
Adipoz doku, prekürsör hücrelerden yeni adipositlerin oluşması ve adiposit ölçüsündeki artışa bağlı olarak büyümektedir (Gregoire ve ark. 1998). Adipogenezis, preadipositlerin olgun yağ hücrelerine dönüşümü olarak tanımlanmaktadır ve yaş ve cinsiyete göre değişen adipoz doku gelişimi söz konusudur. (Coelho ve ark. 2013' da derlendiği gibi). Adipoz dokudaki preadipositlerin yaşam boyunca olgun adipositlere dönüşebilmesi ile, depolama ihtiyacı arttığında ve gerekli olduğunda adipoz dokunun genişlemesi söz konusudur. Aşırı gıda alımında ve depolama ihtiyacına göre olgun adipositler büyüklüklerini artırırlar ve hipertrofik olurlar. Lipidlerin alımı, esterleşmesi, lipolizis ve preadipositlerin farklılaşmasındaki biyokimyasal süreçlere göre enerji dengesine bir cevap oluşturmak için, adiposit sayısı ve morfolojisi değişim göstermektedir (Gray ve Vidal, 2007'dan derlendiği gibi).

Doğum sonrasında, adipoz dokudaki hücrelerin sayı ve ölçüsünün artışına bağlı olarak hızlı bir adipoz doku genişlemesi gözlenir. Yetişkinlerde de yeni preadiposit oluşturma potansiyeli bulunmaktadır. Karbonhidrat ya da yağdan zengin diyetle beslenen ratlarda olduğu gibi diyet faktörlerine bağlı olarak da adiposit hiperplazisi gözlenebilir. Preadipositlerin adipositlere dönüşmesi süreci çok iyi kontrol edilen bir süreçtir. Adipogenezis olgusunda adipojenik dönüştürücü faktörlerden peroksizom çoğaltıcı aktive reseptör (PPAR) $\gamma$, sterol düzenleyici element bağlayan protein1c (SREBP-1) ve C/EBP anahtar rol oynayan faktörlerdir. Adiposit farklılaşması, hormonal ve besinsel sinyallerin etkisine göre pozitif ya da negatif olarak gerçekleşebilir (Gregoire ve ark. 1998).

Adipoz doku enfeksiyon ve travmadan koruma amacıyla derinin altında ve yaşamsal organların çevresinde lokalize olmuştur. Yağ dokunun bakteriyel ve fungal enfeksiyonları genel olarak görülmez, metastazı olağandışıdır, adipoz dokudaki doğuştan veya kazanılmış immun elementlerle olduğu gibi, adipoz olmayan hücre tipleri ve konsantrasyonu ile patojenlere ölümcül olan yüksek düzeydeki lokal yağ asitleri ile nadiren ilişkisi olabilir (Tchkonia ve ark. 2006). Adipositler orijinleri, anatomik dağılımları homeostatik fonksiyonlarına göre beyaz, kahverengi ve bej adipositler/adipoz doku olarak üç tipte sınıflandırılabilir (Şekil 1).

\section{Beyaz Adipoz Doku}

Beyaz adipositler, çoğunlukla insülin olmak üzere değişik uyarıcılara cevap olarak meydana gelen lipogenezis yoluyla, lipidleri trigliserid olarak tek damlacik halinde depolarlar. 
Enerji yetersizliğinde, bu trigliserid depolarının lipolizisini uyaran diğer sinyalizasyonlarla oluşan serbest yağ asitleri dolaşıma katılırlar. (DiSpirito ve Mathis, 2015' de derlendiği gibi).

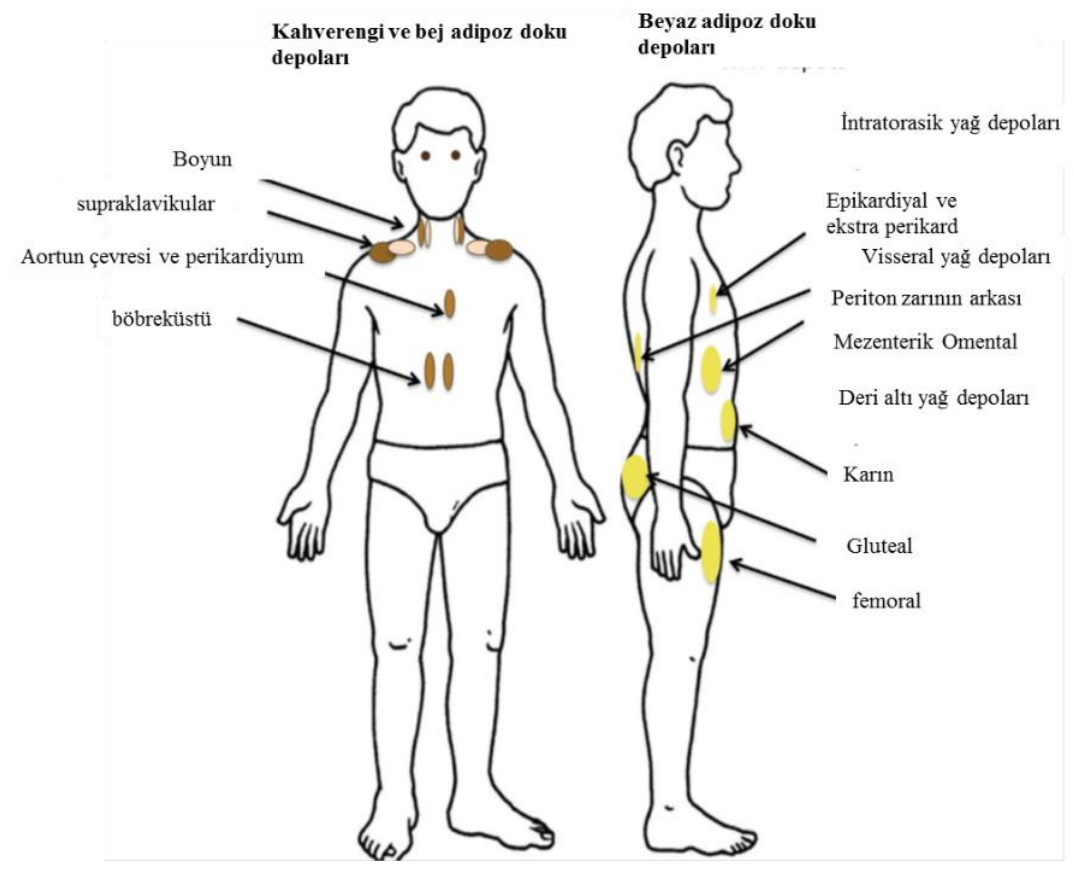

Şekil 1. Kahverengi, beyaz ve bej adipoz dokuların bulundukları bölgeler (Gaggini ve ark. 2015).

Beyaz adipoz doku subkutan ve visseral olarak sınıflandırılmaktadır. Subkutan olanlar derinin altında bulunur ve insanlarda karın ile bacaklarda belirgin elastik odaklar şeklinde bulunmaktadır. Abdominal, mezenterik ve omental odaklar, insanlardaki ana visseral adipoz dokulardır. İnsanlarda omental yağ bölgesi, vücuttaki toplam yă̆ ölçüsünün çoğunu oluşturmaktadır. Kemirgenlerde visseral beyaz adipoz doku örneği olarak alınan epididimal adipoz odak, insandaki omental bölgeye eşit bir fonksiyon gösterebilir. Kemirgenlerde çalışılan visseral adipoz dokular mesenterik ve intraperitoneal olanlardır (DiSpirito ve Mathis, 2015 ' de derlendiği gibi).

Visseral ve subkutan adipoz dokunun yapısal ve fonksiyonel özellikleri farklılıklar göstermektedir (Tablo 1). Subkutan ve visseral adipoz doku arasında; anatomik bölge ve hücresel yapı yanında, moleküler, fizyolojik, klinik ve prognostik açıdan farklılıklar bulunmaktadır. Mezenter ve omentumda bulunan visseral adipoz doku, subkutana göre daha çok hücresel, vasküler, sinirsel innervasyon yapısına sahip olup; daha çok inflamatuar ve immun hücre, daha az preadiposit farkl1laşma kapasitesi ve fazla oranda büyük adiposit bulundurmaktadır. Glikokortikoid ve androjen reseptörleri visseral adipoz dokuda daha çoktur. Subkutanla karşılaştırıldığında metabolik olarak visseral adipositler daha aktif, 
lipolizise daha duyarlı ve insüline karşı daha dirençlidirler. Ayrıca visseral adipoz doku, adrenerjik uyarıma daha duyarlıdır. Daha fazla serbest yağ asitleri oluşturma ve glikoz alma kapasitesine sahiptir. Subkutan adipoz doku, dolaşımdaki serbest yağ asitlerinin ve trigliseridin alınmasında daha etkindir. Visseral adipoz doku ise mortalite oranında subkutana göre daha belirleyicidir (Ibrahim, 2010).

Tablo 1. Visseral ve subkutan adipoz dokunun yapısal ve fonksiyonel özelliklerinin karşılaştırılması

\begin{tabular}{|c|c|c|c|}
\hline Özellikler & Subkutan & Visseral & Kaynaklar \\
\hline Leptin mRNA s1 ve proteini & + & & $\begin{array}{l}\text { Montague ve O'Rahilly, } \\
\text { 2000'de derlendiği gibi }\end{array}$ \\
\hline TZD uyarıcılı preadiposit farklılaşması & + & & $\begin{array}{l}\text { Montague ve O'Rahilly, } \\
2000 \text { 'de derlendiği gibi }\end{array}$ \\
\hline HSL aktivitesi & + & & Reynısdottır ve ark. 1997 \\
\hline HSL mRNA oluşumu & + & & Reynısdottır ve ark. 1997 \\
\hline Lipoliz & + & & Reynısdottır ve ark. 1997 \\
\hline Adiposit büyüklüğg̈ & + & & Reynısdottır ve ark. 1997 \\
\hline İnsulinin antilipolitik etkisi & + & & $\begin{array}{l}\text { Montague ve O'Rahilly, } \\
2000 \text { 'de derlendiği gibi }\end{array}$ \\
\hline İnsulin reseptör affinitesi & + & & $\begin{array}{l}\text { Montague ve O'Rahilly, } \\
\text { 2000'de derlendiği gibi }\end{array}$ \\
\hline IRS-1 protein ekspresyonu & + & & $\begin{array}{l}\text { Montague ve O'Rahilly, } \\
2000 \text { 'de derlendiği gibi }\end{array}$ \\
\hline IRS-1 proteini & + & & $\begin{array}{l}\text { Montague ve O'Rahilly, } \\
\text { 2000'de derlendiği gibi }\end{array}$ \\
\hline $11 \beta$-HSD 1 aktivitesi & & + & $\begin{array}{l}\text { Montague ve O'Rahilly, } \\
\text { 2000'de derlendiği gibi }\end{array}$ \\
\hline PAI-1 proteini & & + & $\begin{array}{l}\text { Montague ve O'Rahilly, } \\
\text { 2000'de derlendiği gibi }\end{array}$ \\
\hline $\begin{array}{l}\text { İnsulin sinyalizasyonunu daha az etkili hale } \\
\text { getiren, exon } 11 \text { 'i eksik yapıya sahip insülin } \\
\text { reseptörü }\end{array}$ & & + & $\begin{array}{l}\text { Montague ve O'Rahilly, } \\
2000 \text { 'de derlendiği gibi }\end{array}$ \\
\hline Glikokortikoid reseptör mRNA s1 & & + & $\begin{array}{l}\text { Montague ve O'Rahilly, } \\
2000 \text { 'de derlendiği gibi }\end{array}$ \\
\hline Androjen mRNA s1 & & + & $\begin{array}{l}\text { Montague ve O'Rahilly, } \\
\text { 2000'de derlendiği gibi }\end{array}$ \\
\hline
\end{tabular}

+ : Daha fazla, TZD:Tiazolidinedone, HSL: Hormon duyarlı lipaz, IRS: İnsulin reseptör substrat, $11 \beta$ HSD1: 11ß-hidroksisteroid dehdrojenaz-1 oxo redüktaz, PAI-1 Plazminojen aktivitör inhibitör-1

Adipositlerin lipidleri depolama ve bırakma kabiliyetleri, insüline yanıtları ve adipokinler aracılığ ile oluşturdukları endokrin etkileri, immun sistem tarafından çok fazla etkilenmektedir. (DiSpirito ve Mathis, 2015’ de derlendiği gibi)

Adipoz doku odakları; öncü hücre proliferasyon oranları, lipojenik ve lipolitik kapasiteleri ve adipokin salg1 profillerine göre fonksiyon olarak farklılık göstermektedir. Diyete bağlı obezitede en çok visseral odakların yangılanması söz konusu olmaktadır (DiSpirito ve Mathis, 2015' de derlendiği gibi).

Leptin ve adiponektin gibi koruyucu adipokinlerin olmadığı adipoz doku eksikliği (lipidodistrofi) durumu ve adipoz olmayan karaciğer, kas ve pankreas gibi dokularda ektopik 
lipid birikimi gibi birbirinden farklı olguların görülebilmesi, beyaz adipoz dokununun önemini ortaya koymaktadır. Aşırı miktarda lipid birikimiyle beslenme dengesine zarar veren ikinci durumda; insülin direnci, kardiyovasküler hastalıklar tetiklenebilir (Unger ve ark. 2010'da derlendiği gibi). Bu nedenle adipozitenin artışı olarak görülen obezite, diyabetes mellitus, insülin direnci, kardiyovasküler hastalıklar, kanser gibi aynı kronik bozuklukların oluşumunda önemli bir risk faktörü olarak görülmektedir. Ancak obez bireylerin önemli bir kısmının metabolik sendrom oluşumuna karşı en azından belli bir dönem için nispeten dirençli olduklarının görülmesi (Appleton ve ark. 2013, Denis ve Obin, 2013' de derlendiği gibi, Voulgari ve ark. 2011), metabolik sağlığa etkili ilave faktörlerin olduğunu ortaya koymaktadır.

Obezitenin oluşumu ile metabolik hastalıkların ortaya çıkmasının göstergesi, adipoz odaklarda görülen hücresel yapı değişiklikleridir (Sun ve ark. 2011'de derlendiği gibi). Obezitede ilk olarak, adipoz doku genişlemesi, varolan adipositlere lipid depolanmasının artması ile adiposit hipertrofisi meydana gelmektedir. Metabolik sendromlu obezlerde adipoz dokunun karakteristik yapısı adiposit hipertrofisi şeklindedir (Sun ve ark. 2011'de derlendiği gibi).

Obez bireylerde büyük hipertrofik adipositlerin yanında, çok sayıda adiposit birikimi ile adiposit sayısında artış veya adiposit hiperplazisi de gözlenebilir. Sağlıklı obez bireyler aynı vücut kitle indeksi olan metabolik sendromlu bireylerle karşılaştırıldığında, sıklıkla daha küçük ve daha çok sayıda adipositle karakterize adipoz yapı fenotipi göstermektedirler. Bu durumda insülin duyarlılı̆̆ında etkili olan adiponektinin dolaşımdaki seviyesinin muhafaza edildiği, düşük seviyede kaldığında ise yangı ve fibrozisle kuvvetli bir ilişkide olduğu da belirtilmektedir (Kloting ve ark. 2010, Sun ve ark. 2014).

Adipoz doku kitlesi orta yaşa doğru artmakta, yaşlılıkta ise azalmaktadır. Yağ kitlesel olarak orta yaş ve sonrasında subkutandan intraabdominal visseral odaklara doğru zamanla yer değiştirmektedir. Genç erkek ve kadınlara göre yaşlılarda gıda ile alınan yağ, subkutan odaklarda daha az depolanmakta ve yetişkin kadınlarda abdominal çevre ölçüsü 9 yılda bir 4 cm artmaktadır (Tchkonia 2010'da derlendiği gibi). Ayrıca abdominal obezite, periferal veya gluteofemoral obeziteye göre diyabet ve kardiyovasküler rahatsılılılar açısından daha risklidir (Ibrahim 2010' da derlendiği gibi). Genel olarak obezite ve yaşl1lıkta oluşan adipoz dokunun yangısal cevapları, bireyleri metabolik fonksiyon bozukluklarına predispoze hale getirebilir (Tchkonia 2010'da derlendiği gibi). 


\section{Kahverengi ve Bej Adipoz Doku}

Kahverengi adipoz doku, lipid oksidasyonuna bağlı olarak titremeyi önleme ya da titrememe termogenezinde yer alan özelleşmiş bir formdur (Choe ve ark. 2016' da derlendiği gibi). Kahverengi adipoz dokunun kahverengi rengi lipid oksidasyonu ve 1s1 oluşumu için önemli olan sahip olduğu yüksek orandaki mitokondri yoğunluğuna atfedilir (Choe ve ark. 2016' da derlendiği gibi). Kahverengi adipoz doku insan ve kemirgenlerin perinatal döneminde interskapular bölgede (DiSpirito ve Mathis, 2015' de derlendiği gibi) ve ayrıca infant-yetişkin rodentlerin her ikisinde görülmesine rağmen, insanda yeni doğanlarda sınırlıdır, yaş ilerledikçe aşamalı bir şekilde beyaz adipoz doku ile yer değiştirdiği bildirilmektedir. Yapılan tomografi (pozitron emisyon/computed) çalışmalarında, kahverengi adipoz dokunun yetişkin insanlarda varlığı ve fonksiyonun olduğu gösterilmiştir (Cypess ve ark. 2009, Virtanen ve ark. 2009). Yetişkin insanlarda boyun ve supraklavikular bölgede kahverengi adiposit benzeri termojenik hücreler bulunmaktadır (DiSpirito ve Mathis, 2015' de derlendiği gibi). Bu nedenle çeşitli adipoz dokular, fazla enerjiyi depolayıp termogenezisi kontrol ederek enerji homeostazisinin merkezi düzenleyicisi olarak görev yapmaktadırlar (Choe ve ark. 2016' da derlendiği gibi).

Beyaz adipoz doku ile karşılaştırıldığında kahverengi adipoz doku, multiloküler lipid damlacıkları, zengin damarlaşma ve fazla sayıda mitokondrisi ile karakterizedir. Adipoz doku çok sayıda $\beta$ adrenerjik reseptör bulundurur ve bu durum soğuğun uyardığı lipolizi başlatır (Choe ve ark. 2016' da derlendiği gibi). Soğuğa maruz kalmanın sonrasında çok fazla miktarda lipidin beyaz adipoz dokudan kahverengi adipoz doku içerisine geçiş yaptığ görülmektedir (Choe ve ark. 2016' da derlendiği gibi). Sonrasında kahverengi adipoz dokudaki $\beta$ adrenerjik sinyalizasyon ile ayrıştırma proteini 1'in (UCP-1) ekspirasyonu ve mitokondriyal genleri stimüle eden PPAR $\gamma$ koaktivatör $1 \alpha^{\prime}$ nın (PGC-1 $\alpha$ ) ekspirasyonu aktifleştirilmektedir (Puigserver ve ark. 1998). UCP-1 ekspiresyonuna ilaveten soğuğun uyardığı kahverengi adipoz doku, mitokondriyal biyogenezisin eşlik ettiği etkili 1sı üretimi için lipid alımını artırmaktadır (Choe ve ark. 2016'da derlendiği gibi). Homeostatik termogenezisin genel modeline göre, soğuğa maruz kalmanın vasküler endoteliyal büyüme faktörü (VEGF) içeren proanjiojenik faktörlerin ekspiresyonunu artırdığı ve kahverengi adipoz dokudaki antianjiojenik faktörlerin ekspiresyonunu engellediği bildirilmektedir (Xue ve ark. 2009). VEGF reseptörü 2‘nin blokaj1, soğuğa bağl1 anjiojenezisi bozar ve 1sı oluşturma kapasitesini olumsuz etkiler ki bu durum kahverengi dokunun anjiojenik yapılanmasının termoregülasyon için önemli bir faktör olduğunu göstermektedir (Xue ve ark. 2009). Yapılan 
çalışmalarda, kahverengi adipoz doku ve subkutan beyaz adipoz dokunun her ikisinin termal regülasyonda katkısı olduğunu öne sürülmektedir (Choe ve ark. 2016'da derlendiği gibi).

A:Beyaz adipoz doku

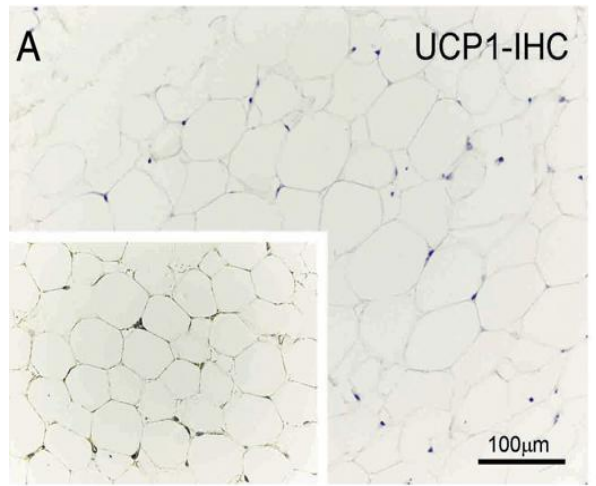

B:Kahverengi adipoz doku

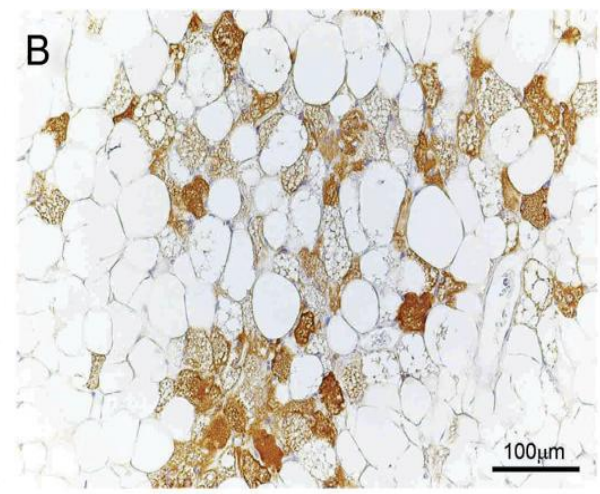

Şekil 2. Beyaz ve soğuğa maruz kalma sonrasında kahverengileşen adipoz doku (Frontini ve ark. 2013).

Beyaz/kahverengi değerlendirmeleri, çevre 1sısına bağlı olarak beyaz adipositlere veya kahverengi adipositlere benzeyen bej (veya brite=brown in white) adipositlerin beyaz adipoz odaklarda keşfi ile yeniden gözden geçirilmiştir. Soğuk ve $\beta$ adrenerjik sinyalizasyon, kahverengi ve bej adipositler için enerji kullanımında önemli uyarıcılardır (Şekil 2). Soğuğa maruz birakılan kemirgenlerde, bej adipositler kahverengi adipositler gibi 1s1 yayabilmektedirler (DiSpirito ve Mathis, 2015' de derlendiği gibi)

Is1 oluşturma fonksiyonunu paylaşmalarına rağmen, bej ve kahverengi adipositler arasında bazı farklılıklar söz konusudur. Bugüne kadar bej rengi adiposit farklılaşması için 2 farklı hipotez öne sürülmüştür. İlki, olgun beyaz adipositlerin transdiferasyonuyla oluştukları, diğeri ise bej adipositlerin spesifik prekürsörlerden farklılaştı̆̆ı şeklindedir (Choe ve ark. 2016'da derlendiği gibi).

Soğuğa maruz kalmanın adipogenezisi oluşturması sonrasında, farelerde subkutan bej adiposit hücre sayısının arttığı gösterilmiştir (Wang ve ark. 2013). Soğuğun uyarması sonucu oluşan bej adipositler, ısının oluşumuna adaptasyon sonrasında tipik beyaz adipositlere dönüşmektedir (Rosenwald ve ark. 2013). Daha sonra oluşan soğuk uyarısı ile bu tipik beyaz adipositler tekrar bej adipositlere dönüşebilmektedir. Fare bej adipositlerinin insan subkutan hücre popülasyonuyla eşit olup olmadığı hala tartışma konusu olmasına rağmen, erişkin insan kahverengi yağ dokunun hem klasik kahverengi adipositleri hem de bej adipositleri içerdiği bildirilmiştir (Jespersen ve ark. 2013, Sharp ve ark 2012). 
Son zamanlarda yapılan gen analizi çalışmalarında, subraklavikular kahverengi adipoz dokunun klasik kahverengi adipozlardan ziyade bej adipositlerden oluştuğu görülmüştür (Choe ve ark. 2016'da derlendiği gibi). Bazı sitokinler bejleşme veya kahverengileşmenin stimülasyonunda etkilidirler. Örneğin; fibroblast büyüme faktörü 21 (FGF21), PGC-1 $1 \alpha^{6} 1$ aktifleştirir, kahverengi adipositlerin fonksiyonunu hızlandırır (Choe ve ark. 2016'da derlendiği gibi). Kemik morfogenetik proteini (BMP)7 de adipositlerin kahverengileşmesi ile ilgilidir (Tseng ve ark. 2008). Kahverengi adipoz doku aktivasyonu ve beyaz adipoz dokunun bejleşmesi obezite ve metabolik hastalıkların tedavisinde önemli hedef konular olabilir (Choe ve ark. 2016'da derlendiği gibi).

\section{Adipokinler}

Adipoz doku endokrin organ olarak kas, karaciğer ve beyin gibi diğer metabolik dokulardan gelen bilgileri almakla kalmaz, aynı zamanda besin dengesini düzenlemek için lokal ve sistemik olarak etki eden 'adipokinler' şeklinde çözünebilir sinyalleri iletir. Ayrıca doğuştan ve kazanılmış immun sistemin hücreleri ile infiltre olmuş bir yapısı vardır. (DiSpirito ve Mathis, 2015' de derlendiği gibi )

Adipokin, genel olarak adipositlerden sentezlenen, otokrin, parakrin ve endokrin etkileri olması nedeniyle (Kershaw ve ark. 2004) hücreden hücreye sinyal taşıyan proteinleri tanımlamak için kullanılan bir terimdir. Adipoz doku, trigliseritin enerji deposu olarak bulundurulduğu esas yerdir. Bunun dışında olgun adipositlerden enzimler, büyüme faktörleri, sitokinler, kemokinler ve hormonlar (adipokinler) gibi proteinler oluşturulmaktadır. $\mathrm{Bu}$ proteinler beslenme, enerji dengesi, lipid ve glikoz metabolizması, yang1, koagulasyon, kardiyovaskuler sistem, insülin duyarlılığı, alternatif komplement sistem, vasküler homeostazis, kan basınc1, anjiojenezis ve akut-faz cevaplar üzerinde değişimler oluşturabilmektedirler (Trayhurn ve Wood, 2004). Bu proteinlerin obezitede artması, akut-faz proteinleri ile inflamatuar sitokinlerinin dolaşımdaki düzeyinin yükselmesi düşük seviyedeki kronik yang1 durumu ile karakterize bir obezliğe neden olmaktadır (Trayhurn ve Wood, 2004'de derlendiği gibi). Bu durum insülin direnci, metabolik sendrom, tip 2 diyabet, kanser (Trayhurn ve Wood, 2004'de derlendiği gibi) ve gestasyonel diyabet (Fasshauer ve ark. 2014'de derlendiği gibi) gibi diğer hastalıkların ortaya çıkmasına aracılık etmektedir. 


\section{Adipoz Dokudaki Proinflamatuar Sitokin Olușturan Hücreler ve Sitokinler}

Adipoz dokuda bulunan immun hücreler aktif bir şekilde pro-ve antiinflamatuar sitokinleri salgılamaktadırlar (Şekil 3). Antiinflamatuar sitokinler, zayıf adipoz dokuda insülin duyarlılığını muhafaza etmeye yardım ederken, obezitedeki proinflamatuar sitokinler insülin direncine yol açmaktadır (Choe ve ark. 2016'da derlendiği gibi). Ayrıca proinflamatuar sitokinler adipositlerde lipolizi uyarır diğer dokularda lipotoksisiteye neden olurlar (Choe ve ark. 2016'da derlendiği gibi). Yüksek yağlı diyetin bir hafta verilmesi ile C57BL/6 farelerin diğer dokularına nazaran özellikle adipoz dokularında yangısal cevaplar oluştuğu, uzun süreli yüksek yağlı diyetle beslemeye bağlı olarak karaciğer ve kası içeren diğer metabolik dokularda da oldukça fazla proinflamatuvar cevap alındığı tespit edilmiştir (Lee ve ark. 2011). $\mathrm{Bu}$ bulgular, kısa süreli aşırı enerji alımının ilk olarak adipoz dokuda yangıya sebep olduğunu, uzun süreli ve yüksek derecede enerji alınımın ise diğer metabolik organlarda da yangıyı başlatabildiğini göstermektedir.

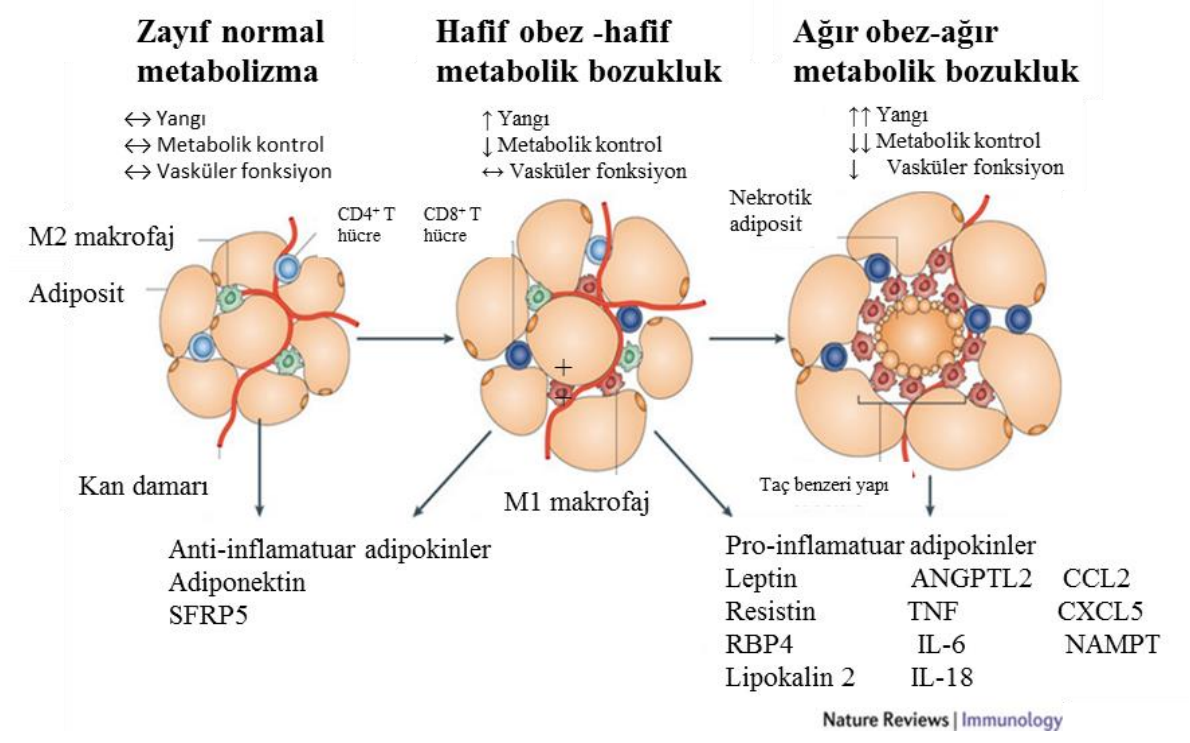

Şekil 3. Zayıf normal metabolizma, hafif obez -hafif metabolik bozukluk ve ağır obez-ağır metabolik bozuklukta salgilanan adipokinler (Ouchi ve ark. 2011).

Adipoz dokunun yeniden yapılanması, adiposit ölçüsündeki değişiklikler gibi, geri dönüşümlü immun hücre kompozisyonundaki değişikliklerle birlikte meydana gelir ki, bu durum bazı adiposit fonksiyonlarını değiştirmektedir (Choe ve ark. 2016 da derlendiği gibi). Yüksek yağlı diyetle beslemeye bağlı olarak nötrofil ve makrofaj sayıları adipoz dokuda hızlıca artmaktadır (Lee ve ark. 2011, Talukdar ve ark. 2012). Nötrofiller kandaki en çok bulunan lökosit tipidir ve yangısal cevaplara kısa sürede reaksiyon vermektedirler (Choe ve 
ark. 2016' da derlendiği gibi). Yüksek yağlı diyetle beslemenin 3 gün sonrasında farelerde nötrofil kaynaklı elastaz ve miyeloperoksidaz ekspresyonlarının arttığı ve bu nötrofillerin obez adipoz dokuda kısa sürede yığın yaptığı (Elgazar-Carmon ve ark. 2008, Talukdar ve ark. 2012), ayrıca nötrofil elastaz inhibitörünün ve aynı enzimin genetik olarak eksik olmasının, yüksek yağlı diyete bağlı adipoz doku yangısı ve insülin direncini hafiflettiği belirlenmiştir (Talukdar ve ark. 2012). Bu sonuçlar adipoz dokudaki insülin direnci ve proinflamatuar cevap oluşumuna nötrofil elastazın katkıda bulunduğunu göstermektedir.

Adipoz doku makrofajları; M1 (klasik aktifleşen) ve M2 (alternatif aktifleşen ) olarak ikiye ayrılır M1 tipi uyarılabilir nitrik oksit sentazı (iNOS), hücre yüzeyindeki CD11c'yi ve TNF- $\alpha$, IL-1 $\beta$ gibi proinflamatuvar sitokinleri eksprese ederken, M2 makrofajlar ise arjinaz, IL-10 ve makrofaj yüzey antikoru Ym-1'i eksprese etmektedir. Adipoz dokudaki M1 makrofaj tipinin adipoz doku yangısı ve obezitedeki insülin direncine esas katkıda bulunan makrofaj tipi olduğu bildirilmektedir (Choe ve ark. 2016' da derlendiği gibi). Ayrıca CD11c pozitif hücrelerinin eksiltildiği kemik iliği ile transplante olan farelerde, diyete bağlı obezite durumunda insülin direnci ve adipoz doku yangısının hafif olduğu gösterilmektedir (Choe ve ark. 2016' da derlendiği gibi). Adipoz doku makrofajlarının bu basit sınıflandırılması bazı deneysel faydalar oluştursa da sadece basit M1 ve M2 gibi sınıflandırmadan ziyade çeşitli adipoz doku makrofaj çeşitlerinin de olduğu bildirilmektedir (Rocha ve ark. 2008).

M1 makrofajlarının polarize olması, interferonlar ya da polisakkaritler tarafından uyarılmaktadır (Rocha ve ark. 2008). T yardımcı lenfosit 1 (Th1) ve CD 8 sayısı obez kişilerin adipoz dokusunda artmaktadır (Nishimura ve ark. 2009, Rocha ve ark. 2008, Winer ve ark. 2009). Farelerde CD8 T hücrelerinin eksik olmasının, adipoz dokudaki M1 makrofaj yığılımını, TNF- $\alpha$ ekspresyonunu ve insülin duyarlılığını azalttığı, buna karşın CD8 T hücreleri ve yüksek yağlı diyetle beslenen farelerden alınan adipoz dokudan oluşturulan kültürde ise CD8 T hücrelerinin proliferasyonu ve TNF- $\alpha$ ekspresyonunun arttığı bildirilmiştir (Nishimura ve ark. 2009). Bu bilgiler yüksek yağlı diyetin neden olduğu adipoz dokuda uyarılan faktörlerin, CD8 T hücrelerini daha fazla aktifleştirdiği, ayrıca CD4-T hücresinin bir alt tipi olan Th1 hücresinin de interferon $\gamma$ ekspresyonuna neden olduğu ve obezitede yoğun bulunduğu tespit edilmiştir (Winer ve ark. 2009).

İnterferon $\gamma$ 'nın, M1 makrofaj hücrelerinin polarizasyonunun yanında adipositlerdeki kemokin ve proinflamatuar sitokinlerin ekspresyonunu uyardığ 1 , bununla birlikte yüksek yağlı diyetle beslenen interferon $\gamma^{\prime}$ siz (knockout) farelerde adipoz doku kütlesinde bir fark 
görülmediği, adipoz doku yangısı ve glikoz toleransının vahşi tip fare ile karşılaştırıldığında daha iyi olduğu belirtilmektedir (Rocha ve ark. 2008).

\section{Tümör nekroz faktör- $\alpha$ (TNF- $\alpha)$}

Proinflamatuar sitokin olan TNF $\alpha$, öncelikli olarak myeloid hücrelerden salınır, IL-6 ve IL-1 $\beta$ gibi diğer yangı sitokinlerinin salınımına neden olur. TNF $\alpha$, insülin direncinde etkili olan beyaz adipoz doku kaynaklı ilk sitokin olarak bildirilmiş ve önceleri adipositlerden salındığı düşünülmesine rağmen kaynağının çoğunluğunun adipoz dokuda bulunan makrofajlar olduğu tespit edilmiştir (Makki ve ark. 2013'de derlendiği gibi).

Obez hayvaların adipoz dokusunda TNF $\alpha$ 'nın çok fazla oluşturulduğu, ancak kendisi ya da reseptörünün azaltılmasının, obez hayvanlarda insülin direncinin oluşumuna karşı koruyucu etki yaptığı belirlenmiştir. Obez insanların plazma ve adipoz dokusunda fazlaca olan TNF $\alpha$ 'nın kilo kaybı ile dolaşımdaki seviyesi azalmaktadır. Son zamanlarda insanlarda yapılan çalışmalar obezite ilişkili insülin direncindeki TNF $\alpha$ 'nın rolünü teyit edici niteliktedir (Makki ve ark. 2013'de derlendiği gibi).

TNF- $\alpha$ 'nın direk olarak insülin duyarlı dokularda insülin sinyalizasyonu ve insülin salınımını azalttığı belirlenmiştir (Dunmore ve Brown 2013' de derlendiği gibi). Bu nedenle, TNF- $\alpha$ etkisinin bloke edilmesi faydalı bir metabolik etki oluşturabilir (Romanatto ve ark. 2009).

Obezite ve diyabetli değişik rodent modellerinde, TNF- $\alpha$ nın antikorlarla nötralize edilmesinin yanında, TNF- $\alpha$ geninin genetik olarak uzaklaştırılmasının insülin duyarlılığını artırdığı tespit edilmiştir (Houseknecht ve ark. 1998'de derlendiği gibi, Li ve ark. 2003, Uysal ve ark. 1997). Ayrıca ratlarda TNF 1 reseptörü aracılı TNF- $\alpha$ sinyalizasyonunun bloke edilmesinin, diyet kaynaklı obezite ve insülin direncine karşı koruyucu olduğu tespit edilmiştir (Liang ve ark. 2008).

TNF $\alpha$ 'nın insülin sinyalizasyondaki direkt negatif etkisine ilaveten, adiposit farklılaşması ve adiposit lipid metabolizmasını değiştirmesi ile indirekt olarak insülin direncini uyarmasının yanında, lipolizisi ve karaciğerde glikoz oluşumunun artmasına katkıda bulunacak olan serbest yağ asidi salınımını başlattığı da bilinmektedir. Ayrıca preadipositlerin olgun adipositlere dönüşümünü inhibe ederek, adipoz doku kitlesinin olası genişlemesine neden olmaktadır. TNF $\alpha$ glikoz ve lipid homeostazisinde etkili olan adiponektinin oluşumunu da olumsuz etkilemekte ve direkt immun yanıtlara etki etmekten çok IL-6 gibi 
diğer sitokinlerin sentezini artmasına katkıda bulunarak etkisini göstermektedir (Makki ve ark. 2013'de derlendiği gibi).

\section{İnterlökin-6 ( IL-6)}

IL-6 yang1, hematopoez, immun cevaplar ve savunma mekanizmasının düzenlenmesinde çok yönlü etkiye sahip bir sitokindir (Makki ve ark. 2013'de derlendiği gibi). IL-6, beyaz adipoz doku, iskelet kası ve karaciğerden salgılanmaktadır (Weisberg ve ark. 2003, Wieckowska ve ark. 2008). Sağlıklı bireylerin dolaşımdaki IL-6' nın 1/3' ü adipoz doku kaynaklı olduğundan adipokin olarak da düşünülmektedir. Adipoz dokudan salgılanan IL-6 nın bir kısmı adipositlerden bir kısmı da özellikle makrofajlar olmak üzere diğer hücrelerden salınmaktadır (Weisberg ve ark. 2003). TNF $\alpha$ 'da olduğu gibi, artan vücut kitlesi, bel çevresi ve serbest yağ asitleri ile ilişkili olarak IL-6 oluşumu da artmaktadır. (Vozarova ve ark. 2001). Kilo kaybı ile IL-6' nın dolaşımdaki seviyesi de azalır (Bastard ve ark. 2000).

IL-6, subkutan adipoz dokudan çok visseral adipoz dokudan salındığı için visseral adipozitenin bir göstergesi olarak görülmektedir (Fried ve ark. 1998' de derlendiği gibi). Ancak çalışmaların bazıları, insülin yanıtı veya etkisiyle ilişkili olmayan adipozite ve yağ kitlesinin IL-6 ile bağlantılı olduğunu belirtirken, bazı araştırmalar da obezite ilişkili insülin direncinde IL-6'nın yüksek seviyelerde olduğunu bildirmektedirler (Makki ve ark. 2013'de derlendiği gibi) . Aslında IL-6, doku ve metabolik durumlara bağlı olarak değişken etkiler gösterebilmektedir. IL-6, egzersiz esnasında antiinflamatuar etkisinin yanı sıra yağ asidi oksidasyonunu, iskelet kası kitlesi hipertrofisi ve miyogenezisi yönlendirecek şekilde glikoz alımını artırırken, adipoz doku ve karaciğerde insülin rezistansını artıracak proinflamatuar aktiviteleri de artırmaktadır (Makki ve ark. 2013'de derlendiği gibi). IL-6; ayrıca mezenşimal kök hücre proliferasyonunu artırıp, hücrelerin (adipojenik ve kondrojenik) farklılaşmasını ve adipogenezisi önleyerek, beyaz adipoz dokuda yă̆ asidi metabolizmasının dengesizliğine öncülük etmektedir (Pricola ve ark. 2009).

Son zamanlarda yapılan bir çalışmada, IL-6'nın GLP-1 sentezindeki artışa bağlı olarak insülin salınımı uyardığg gözlemlenmiş ve buna bağlı olarak oluşan obeziteye bağlı IL6 salınımının, obezitede gelişen insülin direnci durumunda artan insülin salınımı mekanizmasını yansıtabileceği düşünülmektedir (Makki ve ark. 2013'de derlendiği gibi). Beyaz adipoz doku ve karaciğerdeki IL-6 salınımı çok istenen bir durum olmamasına rağmen, iskelet kası için bu durum tam tersidir. IL-6'nın insülinin adipoz dokudaki etkisini azaltıp 
azaltmadığının invivo olarak belirlenmesi gerekmektedir (Makki ve ark. 2013'de derlendiği gibi).

İnsanlarda IL-6 lipolizi uyarır, serbest yağ asidi konsantrasyonunu ve tüm vücut yağ1 oksidasyonunu hipertrigliseridemi oluşturmadan artırır (Van Hall ve ark. 2003). IL-6 adiposit farklılaşmasının diğer belirteçlerinin yanı sıra, insanlarda adipositlerinden adiponektinin salınımı ve ekspresyonunu azaltmaktadır (Sopasakis ve ark. 2004). IL-6'nın obezite dahil metabolik hastalıklarda esas rol oynadığından metabolizma üzerindeki etkisinin öneminin anlaşılması ve açığa çıkarılması önem arz etmektedir (Makki ve ark. 2013'de derlendiği gibi).

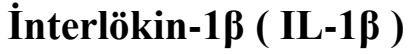

IL-1 (17 kDa ,153 amino asit) sadece immun hücreler tarafından değil, adipoz doku tarafından da salgılanan bir proinflamatuar sitokindir. Dolaşımda albümine bağlı olarak bulunur ve hedef hücrelerde IL-1 reseptörlerine (IL-R1 ve IL-R2) bağlanarak uyarıcı etkisini göstermektedir. Yangısal pankreatik $\beta$ hücresi parçalanmasında ve apoptozisinde önemli bir role sahip olması ve böylece tip 1 diyabetes mellitus'un gelişimine katkıda bulunması söz konusudur. IL-1 $\beta$ 'nın bloke edilmesinin obezite ilişkili insülin direnci ve adipoz doku yangısının azaltılmasında etkili olacağı, böylece aslında daha çok pankreatik $\beta$ hücrelerinin korunabileceği öne sürülmektedir (Fasshauer ve Blüher 2015'de derlendiği gibi). Adiposit farklılaşması esnasında IL-1 $\beta$ 'nın insülin duyarlılığında etkili olan PPAR $\gamma$, adiponektin ve GLUT 4' ün ekspresyonunu azaltarak, adiposit farklılaşmasını ve yağ birikimini azalttığı bildirilmektedir (Tack ve ark. 2012'de derlendiği gibi).

IL-1 ${ }^{\prime}$ nın subkutan adipoz dokuya göre visseral adipoz dokudan daha fazla salgılandığı, glisemik durumdaki bozulmaya göre visseral adipoz dokudan salınımı arasında önemli bir bağlantı olduğu, adipositlerin de içinde olduğu birçok hücreden salındığ 1 bilinmesine rağmen, IL-1 $\beta$ 'nın esas kaynağının insan adipoz dokusundaki makrofajlar olduğu belirtilmektedir (Dalmas ve ark. 2014).

\section{Serum amiloid A (SA A)}

SA ailesinin proteinleri yangıya cevap olarak oluşturulan akut faz proteinleridir (Uhlar veWhitehead, 1999) ve kronik yangı profili olarak obezitede de çalışılmıştır (Yang ve ark. 2006). SA1 ve SA2 akut yang1 esnasında karaciğerde oluşturulur (Uhlar ve Whitehead, 1999) - Doymuş yăg asitleri, IL-1 $\beta$ ve lipopolisakkaritlerin, adipositlerdeki SA3 mRNA 
ekspresyonunu artırdığı çalışmalarda tespit edilmiştir (Larson ve ark. 2003, Sommer ve ark.2008, Yeop Han ve ark. 2010). Adipoz dokunun salgıladığı ve yangı ile ilişkili olan TNF $\alpha$, IL-1 $\beta$, IL-6, IL-8, yanında akut faz yanıtta etkili olan SA A, haptoglobulin ve plazminojen aktivasyonunun inhibe eden-1 (PAI-1) gibi adipokinler salgilanmakta ve bu proteinlerin sentezinin obezitede artması ile insülin direnci ve metabolik sendromla sonuçlanan düşük seviyeli kronik bir yangı durumu söz konusu olmaktadır (Trayhurn ve Wood, 2004).

Adipoz doku yangısı esnasında adiposit kaynaklı faktör olan SA3 geninin makrofajlarla interaksiyonunun araştırıldığı bir çalışmada, obez adipoz dokudaki infiltre olan makrofaj sayısının belirlenmesinde, SA3 gen ekspresyonu seviyesinin kullanılabileceği önerilmiştir (Sanada ve ark. 2016).

HDL'nin fonksiyonel özelliklerinin yangı durumunda adipositler üzerindeki etkisinin incelendiği bir araştırmada; HDL'nin antiinflamatuar özelliğinin kaybolduğu, bu değişimin SAA ile bir bileşik oluşturmuş olan HDL'nin, adiposit hücre yüzeyindeki proteoglikanlara bağlanması ve plazma membranına geçişinin engellenmesi ile oluştuğu tespit edilmiştir (Han ve ark. 2016)

Adipoz dokudan salınan SA’nın, vücut kitle indeksi ile ilişkili olduğu, kilo kaybı ile azaldığı ve kilo kaybı sonrasında görülen insülin duyarlılığındaki gelişmenin serumdaki azalan SA düzeyleri ile ilişkili olduğu belirlenmiş̧tir. Aynı çalışmada, SA'nın adipoz doku kültüründeki lipolizi \% 47 artırdığg, obezitede adipositlerde yapımı artan SA'nın lokal ve sistemik yangı ile serbest yağ asidi üretiminde önemli bir rol oynayabileceği ve bu nedenle obezite ve ilişkili insülin direnci /aterosklerozis oluşumunda direkt bağlantılı olabileceği öne sürülmektedir (Yang ve ark. 2006).

\section{Adipoz Dokuda Antiinflamatuar Sitokin Oluşturan Hücreler ve Sitokinler}

Bağışıklık hücre popülasyonları, adipoz doku yangı yanıtlarına karşı koruyucu olarak iş görmektedirler. M2 makrofajları, kuvvetli bir şekilde arjinaz ekspresyonu yapmakta ve bu enzim iNOS'dan arjinini uzaklaştırmaktadır. Bu durum NO gelişimini inhibe etmekte ve M1 makrofajının fonksiyonunu baskılamaktadır (Choe ve ark. 2016' da derlendiği gibi). Ayrıca M2 makrofajları, antiinflamatuar sitokin olan IL-10 salgılamaktadırlar (Choe ve ark. 2016'da derlendiği gibi). Adipositlere IL-10 ile uygulama yapmanın TNF- $\alpha$ aracılı insülin direncini iyileştirdiği belirtilmektedir (Lumeng ve ark. 2007). Leptin yetersiz obez (od/ob) farelerde 
IL-10'nun iskelet kasına enjeksiyonu ile IL-10 seviyesinin artırıldığı bir çalışmada; TNF- $\alpha$ ekspresyonunun azaldığı, insülin direnci, glikoz intoleransının düzeldiği, obezite ve hiperfaji durumlarında proopiomelanocortin salgılayan nöronlarda, STAT3 fosforilasyonunu uyarmas1 ile olumlu yönde etkilerinin olduğu tespit edilmiştir (Nakata ve ark. 2016).

Adipoz doku inflamasyonu ve insülin duyarlılığında adipoz dokuda bulunan doğal öldürücü T (iNKT) hücrelerinin faydalı etkileri son zamanlarda belirlenmiş ve bu hücrelerin IL-4 ve IL-10 gibi antiinflamatuar sitokinlerin sekresyonuyla ilişkili oldukları bildirilmiştir (Choe ve ark. 2016' da derlendiği gibi).

Diyabet oluşturulmuş obez farelere IL-4 uygulandığında, adipoz doku kitlesi ve yangısının iyileştiği, insülin duyarlılığının geliştiği tespit edilmiştir (Ricardo-Gonzalez ve ark. 2010). IL-4 öncelikli olarak farelerin adipoz dokularında eozinofil tarafindan meydana getirilmektedir (Wu ve ark. 2011). Eozinofil yetersiz fareler vahşi tip fareler ile karşılaştırıldığında eozinofil yetersiz farelerde yüksek yağlı diyetle beslemeye bağlı daha az glikoz toleransı ve M2 tipteki adipoz doku makrofajı hücre sayısında azalma olduğu gösterilmiştir. Buna karşın eozinofile kimyasal olarak etkisi olan IL-5'in çok fazla uygulanması durumunda, glikoz toleransını uyardığı ve adipoz dokuda eozonifil sayısını artırdığı belirlenmiştir (Wu ve ark. 2011). Bu nedenle adipoz dokudaki eozinofillerin M2 makrofaj polarizasyonunu oluşturmasına bağlı olarak insülin duyarlılığını düzenleyebileceği ifade edilmektedir (Choe ve ark. 2016). Son zamanlarda yapılan çalışmalarda; yaşamın erken dönemlerinde maksimal preadiposit proliferasyonun, IL-4R $\alpha$ yolu sinyalizasyonuna ihtiyaç duyduğu ve IL-4 kompleksi enjeksiyonunun bej preadiposit proliferasyonunu uyarmak için yeterli olduğu (Lee ve ark. 2015), ayrıca IL-4 ve IL-33' ün bej adiposit farklılaşmasına öncülük ettiği (Brestoff ve ark. 2015, Lee ve ark. 2015) ortaya konmuştur.

Treg hücrelerinin ( $\mathrm{T}$ lenfosit proliferayonunu baskılayarak düzenleyen hücreler) normal farelerin adipoz dokusunda fazlaca olduğu, buna karşın insülin direnci olan obezlerde ise sayılarının oldukça azaldığı gözlenmiştir. Ayrıca Treg hücrelerinin, IL-10 ve dönüştürücü büyüme faktörü $\beta$ (TGF- $\beta$ ) gibi antiinflamatuar sitokinleri salgılamasının yanında, hücrehücre etkileşimleri yoluyla inflamasyona karşı adipoz dokuyu korudukları belirlenmiştir (Feuerer ve ark. 2009). Treg hücrelerinin, obez olan insan ve farelerin adipoz dokusunda azaldığı tespit edilmiştir (Feuerer ve ark. 2009). Treg hücreleri yetersiz olan farelerde ise, yüksek yağlı diyetin oluşturduğu insülin direnci ve adipoz dokudaki proinflamatuar sitokinlerin inflamasyonu ciddi bir şekilde artmıştır (Feuerer ve ark. 2009). Ayrıca adipoz 
dokudaki lenf düğümlerindeki Treg hücrelerinin IL-10 transkripsiyonun, 136 kat daha yüksek seviyede olduğu bildirilmiştir (Feuerer ve ark. 2009). Bununla birlikte diyete bağlı obezliğe dirençle ilişkili sitokin sinyalizasyon yolağında ve adipoz doku yangısını azaltmada etkili, IL-4 gibi sitokinlerin lipoliz oluşturduğu ve ayrıca antiinflamatuvar makrofaj hücresi ve Treg hücresi gibi antiinflamatuar immunositlerin enerji kaynağı olarak serbest yağ asitlerini tercih ettikleri ifade edilmektedir. (DiSpirito ve Mathis, 2015' de derlendiği gibi)

\section{Enerji homeostazisini düzenleyen adipokinler}

\section{Leptin}

Adipoz dokudan salınan ve doygunluk hissi ile ilişkili olan leptinin keşfi ile (Zhang ve ark. 1994), adipoz dokunun metabolizmadaki etkileri üzerindeki algılar değişmeye başlamıştır. Leptin; adipositlerden salınan, 16 kDa ağırlığında olan bir polipeptidtir (Fried ve ark. 2000'de derlendiği gibi). Etkisini beyin ve vücudun periferal bölgelerinde bulunan reseptörü aracılığı ile gösteren bir hormondur (Proença ve ark. 2014' de derlendiği gibi).

Leptin; doygunluk hissi, iştah, gıda alımı, üreme fonksiyonu, fertilite, puberte, aktivite, enerji harcanması, aterogenezisde önemli role sahiptir (Blüher ve Mantzoros, 2015, Mantzorosve ark. 2011'de derlendiği gibi). Leptinin gıda alımını inhibe etmesinin yanında, adipoz dokudaki spesifik metabolik yolakları etkilemesi ile lipid depolanmasını sınırlandırdı ğı iyi bilinmektedir. Leptin, yă̆ asidi sentezini baskılayıp, oksidasyonunu uyararak adipositlerden gliserol salınımına neden olmaktadır. Bu fonksiyonu yağ asidi ve trigliserid sentezinde etkili genlerin oluşumunu azaltarak sağlamaktadır (Oswal ve Yeo, 2003'de derlendiği gibi). Ayrıca leptinin kortizol, TSH, LH ve FSH'nın günlük ritimlerinin düzenlenmesinde, nörogenezis ve beyin fonksiyonlarının kontrolünde etkileri vardır. İmmun cevabı artırmanın yanında yang1, koagülasyon, fibrinolizis ve platelet agregasyonunda da leptinin düzenleyici etkileri bulunmaktadır (Paz-Filho ve ark. 2011). Leptin büyümenin düzenlenmesi, metabolizma ve yeme davranışındaki etkilerini gıda alımı, vücut ağırlığı ve lipid depolanmasını dengeleyen hipotalamus üzerinden yapmaktadır. Plazmadaki leptin seviyesi vücut yağ oranı ile pozitif ilişkili olduğundan, obezlerde zayıflardan çok daha fazla salgılanmaktadır. İskelet kası, meme bezi epitel hücreleri, plasenta ve gastrik fundus mukozası da leptin oluşturulan diğer bölgelerdir (Fried ve ark. 2000'de derlendiği gibi).

Leptinin etkileri hipotalamusla sınırlı değildir (Fried ve ark. 2000'de derlendiği gibi). Açlık duyumunu uyaran ghrelin'in etkilerini inhibe etmekte (Bames ve ark. 2015'de 
derlendiği gibi) ve iskelet kasında adenozin monofosfat kinaz (AMPK) aktivasyonu yoluyla yağ asidi oksidasyonunu artırarak direkt etki yapmaktadır (Minokoshi ve ark. 2002).

Leptin reseptörlerinin sinyalizasyonu ya da fonksiyonunun azalması, leptinin gida alımındaki baskılayıcı etkisini azaltır ve enerji harcanmasını düşürür. Buna istinaden oluşan leptin yetersizliği; obezite, hipogonadizm, hiperinsülinemi, hiperfaji ve T lenfositlerdeki immun yetersizlikle sonuçlanır (Proença ve ark. 2014'de derlendiği gibi). Obezitedeki yüksek plazma leptin seviyelerinin, insülin direnci ile ilişkili olduğu araştırmalarda, izole edilmiş adipositlerdeki insülin duyarlılığının azalması, pankreas $\beta$ hücrelerinden insülin salınımının inhibe edilmesinde leptinin etkili olduğu gösterilmiştir (Schaffler ve ark. 2007'de derlendiği gibi).

Metabolik etkilerinin yanında immun sistem üzerinde de etkileri olduğu tespit edilmiş, CD295 ya da LEP-R olarak bilinen leptin reseptörünün nötrofil, makrofaj ve doğal öldürücü (NK) hücreler üzerinde eksprese edildiği belirlenmiştir (Wensveen ve ark. 2015'de derlendiği gibi). Yapılan bir çalışmada, leptinden $(o b / o b)$ ya da LEP-R den yetersiz $(d b / d b)$ fareler, doyma hissi olmadığından aşırı gıda alımına bağlı olarak obezleşmişlerdir. Ayrıca fonksiyonel immun hücreler olan T hücreleri, NK hücreleri ve dendritik hücrelerde ciddi bir azalma gözlenmiştir (Wensveen ve ark 2015'de derlendiği gibi). T ve B hücrelerinin aktifleştiğinde LEP-R ekspresyonunu artırdığg ve hücre kültürüne leptin ilave edildiğinde aktifleşen lenfositlerin canlılıklarının arttığı tespit edilmiştir (Papathanassoglou ve ark. 2006).

Adipoz dokunun leptin üretimini artırması, obeziteye bir yanıt olarak visseral adipoz dokuda immun hücre artışı için bir tetikleme mekanizması olabilir (Wensveen ve ark 2015'de derlendiği gibi). Yüksek yağlı diyetle beslemenin ilk haftalarında visseral adipoz dokudaki makrofaj ve NK hücreleri sayıca ve fonksiyon olarak artış gösterirlerken, leptinden (ob/ob) yetersiz farelerde azalmışlardır (Wensveen ve ark 2015'de derlendiği gibi). Leptin enjeksiyonunun ratların dolaşımındaki granülosit, monosit ve NK hücrelerinin sayısını artırdığı ve kemik iliğinde NK hücrelerinin canlılığını iyileştirdiği tespit edilmiştir (Wensveen ve ark 2015'de derlendiği gibi). Günümüzde leptin keşfinden klinik kullanımına kadar başarılı bir yol takip eden, iyi bir adipokin olarak görülmektedir.

\section{Adiponektin}

Adiponektin insülin duyarlılaştırma, antiinflamatuar, antiaterosklerotik etkilerinin yanında antikanser, kalp koruyucu etkisi ve dişi üreme sisteminde de faydalı etkilerinin 
olduğu ifade edilen pleotropik etkili bir adipokindir. Adiponektinin sadece adipoz dokudan değil, fare ve insan kardiyomyositlerinden ve fare ve insan iskelet kasından da salındığ tespit edilmiştir (Brochu-Gaudreau ve ark. 2010’ da derlendiği gibi).

Dolaşımdaki adiponektinin düşük moleküler ağırlıkta trimer yapıda, orta molekül ağırlıklı hexamer ve yüksek moleküler ağırlıklı multimerik (12-18 merik) yapılarda olacak şekilde farklı formları tanımlanmıştır. İnsulin duyarlılığıyla ilişkili olması ve tip 2 diyabette multimerik yapıdaki adiponektinin az olması nedeniyle, adiponektinin aktif olan formunun yüksek moleküler yapıya sahip olan formu olduğu tespit edilmiştir (Waki ve ark. 2003). Adiponektinin, bağlandığı reseptör türüne göre hücre içinde farklı sinyalizasyon yolaklarını aktifleştirdiği, AdipoR1 ve AdipoR2 olmak üzere iki tip reseptörü olduğu, bunlardan AdipoR1'in AMPK fosforilasyonunda, AdipoR2 nin ise PPAR- $\alpha$ aktivasyonunda etkili olduğu bildirilmektedir (Lee ve ark. 2008). Ayrıca, AdipoR1'in çoğunlukla iskelet kasında, AdipoR2'nin ise en fazla karaciğerde eksprese edildiği belirtilmektedir (Yamauchi ve ark. 2003 'den alındığg gibi).

Adiponektin adipoz dokudaki otokrin etkisini; preadipositlerden adipositlere farklılaşması ve proliferasyonu başlatması, adipogenezisden sorumlu genlerin programlandırılmasını iyileştirmesi, adipositlerin glikoz taşıma sistemlerinin insüline cevabını ve hücre lipid içeriğini artırması ile göstermektedir (Fu ve ark. 2005).

Adiponektinin plazma seviyelerinin vücut kitle indeksi (Golubović ve ark. 2013) ve visseral adipozite ile oransal açıdan ters ilişkili olduğu (Motoshima ve ark. 2002) belirtilmektedir. Vücut kitle indeksi $\geq 30$ olan obez bayanlarda yapılan bir çalışmada, vücut ağırlığı ile beraber merkezi bölgede yağ artışıyla karakterize obezlikte, insülin duyarlılığında azalma ve glisemik düzensizlik gibi bozukluklara adipoz dokudan salınan leptin ve adiponektin değişimlerinin de katkıda bulunduğu ve ayrıca adiponektinin kilo kaybı sonrasında insülin duyarlılığının iyileşmesinde daha etkin bir role sahip olduğu ifade edilmektedir (Golubović ve ark. 2013).

Normal beden ağırlığında adipoz dokunun kontrolü dengededir ve sağlıklı adipoz dokuda M2 durumundaki adipoz doku makrofajları gibi tip 2 polarize immun sistem hücreleri bulunmaktadır. Bu dengeli durumdaki baskın immun hücreler; IL-4, IL-13 ve IL-10 oluşturan sırasıyla eozinofil, iNKT ve Treg hücreleridir. Adipositler, adiponektin salgıları ile tip 2 immun cevaba katkıda bulunurlar (Wensveen ve ark 2015' de derlendiği gibi). 
TNF $\alpha$ ve interlöykinler, insan adipoz dokusundaki adiponektinin ekspresyon ve sekresyonunu inhibe etmektedirler (Ibrahim, 2010'da derlendiği gibi). Adiponektinin güçlü antiinflamatuvar etkisi vardır ve invitro çalışmalarda M2 makrofajlarda yüksek düzeyde adiponektin resptörünün eksprese edildiği, NF-kB aktivasyonunu inhibe ettiği, makrofajların IL-10 ve ILRa oluşturmasına aracılık ettiği ve diyete bağlı gelişen insülin direncinde önemli etkisi olan TLR4 sinyalizasyonunu baskıladığı yapılan çalışmalarda ortaya konmuştur (Wensveen ve ark 2015'de derlendiği gibi).

İnvitro olarak yapılan bir araştırmada M1 makrofajlarının AdipoR ekspresyonunu bloke ettiği (\%40-60), M2 makrofajların ise bu ekspresyonu muhafaza ettiği bildirilmektedir. Aynı araştırmada M1 makrofaj ortamında adiponektinin, TNFa, IL-6 ve IL-12 gibi proinflamatuvar sitokinler ile AdipoR seviyelerini artırırken, M2 makrofaj ortamında AdipoR ekspresyonunda değişim yapmadan, antiinflamatuar sitokinlerden IL-10 u uyardığı tespit edilmiştir. Elde edilen bulgulara göre makrofaj polarizasyonunun AdipoR ekspresyonunu ve adipokin aracılı makrofajların yangısal cevaplarının düzenlenmesinde önemli bir belirleyici olduğu ilk kez ortaya konmuştur (Van Stijn ve ark. 2015). Adiponektinin fazlaca eksprese edilmesi, obez kemirgenlerde yüksek yağlı diyetle oluşturulan hepatik lipid birikimini önlerken (Kim ve ark. 2007), leptin yetersiz obez (ob/ob) farelerde adiponektinin elimine edilmesi hepatosteatozis oluşturmuştur (Holland ve ark. 2013).

İnsanlarda yapılan çalışmalarda adiponektin seviyesinin azalmasına neden olan adiponektini kodlayan genin polimorfizmi ile diyabet prevalansının arttığ 1 belirlenmiştir (Hara ve ark. 2002, Stumvoll ve ark. 2002). Adipositlerden salınan adiponektinin epidemiyolojik olarak kandaki düşük seviyeleri obezite, insülin direnci, tip 2 diyabet ve kardiyovasküler hastalıklarla ilişkilendirilmiştir (Fu ve ark. 2005).

Adiponektin damar düz kas hücrelerinin proliferasyonunu, TNF- $\alpha$ arac1lı monosit adhezyon moleküllerinin ekspresyonunu ve endotelyal yangı cevabını inhibe ederek ayrıca makrofajların köpük hücrelere dönüşümünü baskılayarak, antiaterojenik bir etki göstermektedir (Ibrahim 2010'da derlendiği gibi). Adiponektinin, in vitro ve invivo olarak anjiojenezisi uyardı̆̆ı, endotel hücredeki nitrik oksit sentezini başlattığ (Ouchi ve ark. 2004). Büyük moleküler yapıdaki adiponektinin endotelial apoptozisi önlediği invitro olarak gösterilmiştir (Kobayashi ve ark. 2004). Adiponektin ayrıca $o b / o b$ farelerde alkole bağlı olmayan karaciğer yağlanmasını ve KK-Ay obez farelerde LPL aracılı karaciğer hasarını önleyerek karaciğerin korunması, kardiyovasküler hastalıkların azaltılması, tümör 
oluşumunun önlenmesi, insan kondrositlerinde IL-8 in oluşumunun artırılması gibi birçok metabolik etkiye sahip olduğu bildirilmektedir (Proença ve ark. 2014'de derlendiği gibi).

Sonuç olarak adipoz dokunun bahsedilen bu özellikleri fizyolojik kapsamda değerlendirildiğinde, adipokin salgısı normaldir ve tüm vücut dengesine ve dolayısı ile sağlıklı olmaya katkıda bulunabilir. Bununla birlikte kronik olarak enerji dengesinin bozulması; adiposit hipertrofisi, adipoz doku yangısı ve bölgesel yă̆ depolanmaları gibi durumlarla karakterize adipoz doku fonksiyonunun bozulduğu durumlara, sonuç olarak da metabolik, kardiyovasküler ve yangısal hastalıklar ile kansere yol açmaktadır. Bahsi geçen metabolik bozuklukların ve mortalitenin azaltılması ve yaşam kalitesinin artırılması için obezite ilişkili yeni adipokinlerin keşfi, bazı adipokinlerin baskılanması ve/ veya salgısının artırılması ile ilgili şu ana kadar yapılmış olan çalışmalara ek olarak yeni çalışmaların yapılmasına ihtiyaç vardır.

\section{Kaynaklar}

1. Ahima RS, Flier JS. 2000. Adipose tissue as an endocrine organ. Trends Endocrinol. Metabol. 11: 327-332.

2. Appleton SL, Seaborn CJ, Visvanathan R, ve ark. 2013. Diabetes and cardiovascular disease outcomes in the metabolically healthy obese phenotype. Diabetes Care, 36: 2388-2394.

3. Barnes MA, Carson MJ, Nair MG. 2015. Nontraditional cytokines: How catecholamines and adipokines influence macrophages in immunity, metabolism and the central nervous system. Cytokine. 72: 210-219.

4. Bastard JP, Jardel C, Bruckert E, et al. 2000. Elevated levels of interleukin 6 are reduced in serum and subcutaneous adipose tissue of obese women after weight loss. J. Clin. Endocrinol. Metab. 85: 3338-3342.

5. Birsoy K, Festuccia WT, Laplante M. 2013. A comparative perspective on lipid storage in animals. J. Cell Sci. 126: 1541-1552.

6. Blüher M, Mantzoros CS. 2015. From leptin to other adipokines in health and disease: Facts and expectations at the beginning of the 21 st century. Metabolism. 64: 131-145.
7. Brestoff JR, Kim BS, Saenz SA, ve ark. 2015. Group 2 innate lymphoid cells promote beiging of white adipose tissue and limit obesity. Nature.;519: 242-246.

8. Brochu-Gaudreau K, Rehfeldt C, Blouin R, ve ark. 2010. Adiponectin action from head to toe. Endocrine. 37: 11-32.

9. Choe SS, Huh JY, Hwang IJ, ve ark. 2016. Adipose tissue remodeling: Its role in energy metabolism and metabolic disorders. Front. Endocrinol (Lausanne) 7: 30.

10. Coelho M, Oliveira T, Fernandes R. 2013. Biochemistry of adipose tissue: An endocrine organ. Arch. Med. Sci. 9: 191-200.

11. Cypess AM, Lehman S, Williams G, ve ark. 2009. Identification and Importance of Brown Adipose Tissue in Adult Humans. N. Engl. J. Med. 360: 1509-1517.

12. Dalmas E, Venteclef $\mathrm{N}$, Caer $\mathrm{C}$, et alve ark. 2014. T cell-derived IL-22 amplifies IL-1betadriven inflammation in human adipose tissue: relevance to obesity and type 2 diabetes. Diabetes. 2014;63: 1966-1977. 
13. Denis G V., Obin MS. 2013. Metabolically healthy obesity: Origins and implications. Mol. Aspects Med. 34: 59-70.

14. DiSpirito JR, Mathis D. 2015. Immunological contributions to adipose tissue homeostasis. Semin. Immunol. 27: 315-321.

15. Dunmore SJ, Brown JEP. 2013. The role of adipokines in beta-cell failure of type 2 diabetes. J Endocrinol. 216: T37-45.

16. Elgazar-Carmon V, Rudich A, Hadad N, ve ark. 2008. Neutrophils transiently infiltrate intraabdominal fat early in the course of high-fat feeding. J. Lipid Res. 49: 1894-1903.

17. Fasshauer M, Blüher M. 2015. Adipokines in health and disease. Trends Pharmacol. Sci. 36: 461-470

18. Fasshauer M, Blüher M, Stumvoll M. 2014. Adipokines in gestational diabetes. Lancet Diabetes Endocrinol. 2:488-499.

19. Feuerer M, Herrero L, Cipolletta D, ve ark. 2009. Lean, but not obese, fat is enriched for a unique population of regulatory $\mathrm{T}$ cells that affect metabolic parameters. Nat. Med. 15: 930-939.

20. Fried SK, Bunkin DA, Greenberg AS. 1998. Omental and subcutaneous adipose tissues of obese subjects release interleukin-6: Depot difference and regulation by glucocorticoid. J. Clin. Endocrinol Metab. 83: 847-850.

21. Fried SK, Ricci MR, Russell CD, ve ark.. 2000. Regulation of leptin production in humans. J. Nutr; 130: 3127S-3131S.

22. Frontini A, Vitali A, Perugini J, ve ark. 2013. White-to-brown transdifferentiation of omental adipocytes in patients affected by pheochromocytoma. Biochim. Biophys. Acta Mol. Cell Biol. Lipids. 1831: 950-959.

23. Fu Y, Luo N, Klein RL, ve ark. 2005. Adiponectin promotes adipocyte differentiation, insulin sensitivity, and lipid accumulation. J Lipid Res. 46: 1369-1379.

24. Gaggini M, Saponaro C, Gastaldelli A. 2015. Not all fats are created equal: Adipose vs. ectopic fat, implication in cardiometabolic diseases. Horm. Mol. Biol. Clin. Investig. 22: 7 18 .

25. Golubović MV, Dimić D, Antić S, ve ark. 2013. Relationship of adipokine to insulin sensitivity and glycemic regulation in obese women--the effect of body weight reduction by caloric restriction. Vojnosanit. Pregl. 70: 284-291.

26. Gray SL, Vidal-Puig AJ. 2007. Adipose tissue expandability in the maintenance of metabolic homeostasis. Nutr. Rev. 65(Suppl.1): 7-12.

27. Gregoire FM, Smas CM, Sul HS. 1998. Understanding adipocyte differentiation. Physiol. Rev. 78: 783-809.

28. Han CY, Tang C, Guevara ME, ve ark. 2016. Serum amyloid A impairs the antiinflammatory properties of HDL. J Clin. Invest. 126: 266-281.

29. Hara K, Boutin P, Mori Y, ve ark. 2002. Genetic variation in the gene encoding adiponectin is associated with an increased risk of type 2 diabetes in the Japanese population. Diabetes. 51: 536-540.

30. Holland WL, Adams AC, Brozinick JT, ve ark. 2013. An FGF21-adiponectin-ceramide axis controls energy expenditure and insulin action in mice. Cell Metab. 17: 790-797.

31. Houseknecht KL, Baile CA, Matteri RL, ve ark. 1998. The Biology of Leptin: A Review. J. Anim. Sci. 76: 1405-1420.

32. Ibrahim MM. 2010. Subcutaneous and visceral adipose tissue: structural and functional differences, Obes. Rev., 11: 11-18.

33. Jespersen NZ, Larsen TJ, Peijs L, et al. 2013. A classical brown adipose tissue mrna signature partly overlaps with brite in the supraclavicular region of adult humans. Cell Metab. 17: 798-805.

34. Kershaw EE, Flier JS. 2004. Adipose tissue as an endocrine organ. J. Clin. Endocrinol. Metab. 89: 2548-2556.

35. Kim JY, Van De Wall E, Laplante M, et al. 2007. Obesity-associated improvements in metabolic profile through expansion of adipose tissue. J. Clin. Invest. 117: 2621-2637.

36. Klöting N, Fasshauer $M$, Dietrich A, ve ark. 2010. Insulin-sensitive obesity. Am. J. Physiol. Endocrinol. Metab. 299: E506-E515.

37. Kobayashi H, Ouchi N, Kihara S, ve ark. 2004. Selective suppression of endothelial cell apoptosis by the high molecular weight form of adiponectin. Circ. Res. 94: e27-e31.

38. Larson MA, Wei SH, Weber A, ve ark. 2003. 
Induction of human mammary-associated serum amyloid A3 expression by prolactin or lipopolysaccharide. Biochem. Biophys. Res. Commun. 301: 1030-1037.

39. Lee MH, Klein RL, El-Shewy HM, ve ark. 2008. The adiponectin receptors AdipoR1 and AdipoR2 activate ERK1/2 through a Src/Rasdependent pathway and stimulate cell growth. Biochemistry. 47: 11682-11692.

40. Lee M-W, Odegaard JI, Mukundan L, ve ark. 2015. Activated Type 2 Innate Lymphoid Cells Regulate Beige Fat Biogenesis. Cell. 160: 74-87.

41. Lee YS, Li P, Huh JY, ve ark. 2011. Inflammation is necessary for long-term but not short-term high-fat diet-induced insulin resistance. Diabetes. 60: 2474-2483.

42. LeRoith D, Novosyadlyy R, Gallagher EJ, ve ark. 2008. Obesity and type 2 diabetes are associated with an increased risk of developing cancer and a worse prognosis; epidemiological and mechanistic evidence. Exp. Clin. Endocrinol. Diabetes. 116 (Suppl):S4-S6.

43. Li Z, Yang S, Lin H, ve ark. 2003. Probiotics and antibodies to TNF inhibit inflammatory activity and improve nonalcoholic fatty liver disease. Hepatology. 37: 343-350.

44. Liang H, Yin B, Zhang H, et al. 2008. Blockade of tumor necrosis factor (TNF) receptor type 1mediated TNF-\{alpha $\}$ signaling protected Wistar rats from diet-induced obesity and insulin resistance. Endocrinology. 149: 2943-2951.

45. Lumeng CN, Bodzin JL, Saltiel AR. 2007. Obesity induces a phenotypic switch in adipose tissue macrophage polarization. J. Clin. Invest. 117: $175-184$

46. Makki K, Froguel P, Wolowczuk I. 2013. Adipose tissue in obesity-related inflammation and insulin resistance: cells, cytokines, and chemokines. ISRN Inflamm. 2013:139239.

47. Mantzoros CS, Magkos F, Brinkoetter M, ve ark. 2011. Leptin in human physiology and pathophysiology. Am. J. Endocrinol. Metab. 301: E567-E584.

48. Minokoshi Y, Kim Y-B, Peroni OD, ve ark. 2002. Leptin stimulates fatty-acid oxidation by activating AMP-activated protein kinase. Nature. 415: 339-343.

49. Montague CT, O’Rahilly S. 2000. The perils of portliness: Causes and consequences of visceral adiposity. Diabetes. 49: 883-888.
50. Motoshima H, Wu X, Sinha MK, ve ark. 2002. Differential regulation of adiponectin secretion from cultured human omental and subcutaneous adipocytes: Effects of insulin and rosiglitazone. J. Clin. Endocrinol. Metab. 87: 5662-5667.

51. Nakata M, Yamamoto S, Okada T, ve ark. 2016. IL-10 gene transfer upregulates arcuate POMC and ameliorates hyperphagia, obesity and diabetes by substituting for leptin. Int. J. Obes. 40: 425-433.

52. Nishimura $S$, Manabe I, Nagasaki $M$, ve ark. 2009. CD8+ effector T cells contribute to macrophage recruitment and adipose tissue inflammation in obesity. Nat. Med. 15: 914-920.

53. Oswal A, Yeo G. 2010. Leptin and the Control of Body Weight: A Review of Its Diverse Central Targets, Signaling Mechanisms, and Role in the Pathogenesis of Obesity. Obesity. 18: 221-229.

54. Ouchi N, Parker JL, Lugus JJ, ve ark. 2011. Adipokines in inflammation and metabolic disease. Nat. Rev. Immunol. 11: 85-97.

55. Ouchi N, Kobayashi H, Kihara S, ve ark. 2004. Adiponectin stimulates angiogenesis by promoting cross-talk between AMP-activated protein kinase and Akt signaling in endothelial cells. J. Biol. Chem. 279: 1304-1309.

56. Papathanassoglou E, El-Haschimi K, Li XC, ve ark. 2006. Leptin receptor expression and signaling in lymphocytes: kinetics during lymphocyte activation, role in lymphocyte survival, and response to high fat diet in mice. J. Immunol. 176 :

7745-7752.

57. Paz-Filho G, Wong ML, Licinio J. 2011. Ten years of leptin replacement therapy. Obes. Rev. 12 :

e315-e323.

58. Pricola KL, Kuhn NZ, Haleem-Smith H, ve ark. 2009. Interleukin-6 maintains bone marrowderived mesenchymal stem cell stemness by an ERK1/2-dependent mechanism. J. Cell Biochem. 108: $577-588$.

59. Proença ARG, Sertié RAL, Oliveira AC, ve ark. 2014. New concepts in white adipose tissue physiology. Brazilian J. Med. Biol. Res. 47:192205.

60. Puigserver P, Wu Z, Park CW, ve ark. 1998. A cold-inducible coactivator of nuclear receptors linked to adaptive thermogenesis. Cell. 92: 829839 . 
61. Reynisdottir S, Dauzats $M$, Thörne A, ve ark. 1997. Comparison of hormone-sensitive lipase activity in visceral and subcutaneous human adipose tissue. J. Clin. Endocrinol. Metab. 82: $4162-4166$.

62. Ricardo-Gonzalez RR, Red Eagle A, Odegaard JI, ve ark. 2010. IL-4/STAT6 immune axis regulates peripheral nutrient metabolism and insulin sensitivity. Proc. Natl. Acad. Sci. 107: 22617-22622.

63. Rocha VZ, Folco EJ, Sukhova G, ve ark. 2008. Interferon- $\gamma$, a Th1 cytokine, regulates fat inflammation: A role for adaptive immunity in obesity. Circ. Res.;103: 467-476.

64. Romanatto T, Roman EA, Arruda AP, ve ark. 2009. Deletion of tumor necrosis factor- $\alpha$ receptor 1 (TNFR1) protects against diet-induced obesity by means of increased thermogenesis. J. Biol. Chem. 284: 36213-36222.

65. Rosenwald M, Perdikari A, Rülicke T, ve ark. 2013. Bi-directional interconversion of brite and white adipocytes. Nat. Cell Biol. 15: 659-667.

66. Sanada Y, Yamamoto T, Satake R, ve ark. 2016. Serum amyloid A3 gene expression in adipocytes is an indicator of the interaction with macrophages. Sci. Rep.6: 38697.

67. Schäffler A, Schölmerich J, Salzberger B. 2007.Adipose tissue as an immunological organ: Toll-like receptors, C1q/TNFs and CTRPs. Trends Immunol. 28: 393-399.

68. Sharp LZ, Shinoda K, Ohno H, ve ark. 2012. Human BAT Possesses Molecular Signatures That Resemble Beige/Brite Cells. PLoS One.7: e49452.

69. Sommer G, Weise S, Kralisch S, ve ark. 2008. The adipokine SAA3 is induced by interleukin$1 \beta$ in mouse adipocytes. J. Cell. Biochem. 104: 2241-2247.

70. Sopasakis VR, Sandqvist M, Gustafson B, ve ark. 2004. High local concentrations and effects on differentiation implicate interleukin-6 as a paracrine regulator. Obes. Res. 12: 454-460.

71. Stumvoll M, Tschritter O, Fritsche A, ve ark. 2002. Association of the $T-G$ polymorphism in adiponectin (Exon 2) with obesity and insulin sensitivity: Interaction with family history of type 2 diabetes. Diabetes. 51: 37-41.
72. Sun K, Park J, Gupta OT, ve ark. 2014. Endotrophin triggers adipose tissue fibrosis and metabolic dysfunction. Nat. Commun. 5: 3485.

73. Sun K, Kusminski CCM, Scherer PEP. 2011. Adipose tissue remodeling and obesity. J. Clin. Invest. 121: 2094-2101.

74. Tack CJ, Stienstra R, Joosten LAB, ve ark. 2012. Inflammation links excess fat to insulin resistance: The role of the interleukin-1 family. Immunol. Rev. 249: 239-252.

75. Talukdar S, Oh DY, Bandyopadhyay G, et al. 2012. Neutrophils mediate insulin resistance in mice fed a high-fat diet through secreted elastase. Nat. Med. 18: 1407-1412.

76. Tchkonia T, Corkey BE, Kirkland JL. 2006. Current Views of the Fat Cell as an Endocrine Cell: Lipotoxicity. Bray GA, Ryan DH, ed. Overweight and the Metabolic Syndrome: From Bench to Bedside. Boston, MA: Springer US, s. 105-123.

77. Tchkonia T, Morbeck DE, Von Zglinicki T, ve ark. 2010. Fat tissue, aging, and cellular senescence. Aging Cell. 9: 667-684.

78. Trayhurn P, Wood IS. 2004. Adipokines: inflammation and the pleiotropic role of white adipose tissue. Br. J. Nutr. 92: 347-355.

79. Tseng Y-H, Kokkotou E, Schulz TJ, ve ark. 2008. New role of bone morphogenetic protein 7 in brown adipogenesis and energy expenditure. Nature. 454:1000-1004.

80. Uhlar CM, Whitehead AS. 1999. Serum amyloid A, the major vertebrate acute-phase reactant. Eur. J. Biochem. 265: 501-523.

81. Unger RH, Clark GO, Scherer PE, ve ark. 2010. Lipid homeostasis, lipotoxicity and the metabolic syndrome. Biochim. Biophys. Acta - Mol. Cell Biol. Lipids. 1801: 209-214.

82. Uysal KT, Wiesbrock SM, Marino MW, ve ark. 1997. Protection from obesity-induced insulin resistance in mice lacking TNF- alpha function. Nature. 389: 610-614.

83. Van Gaal LF, Mertens IL, De Block CE. 2006. Mechanisms linking obesity with cardiovascular disease. Nature. 444: 875-880.

84. Van Hall G, Steensberg A, Sacchetti M, et al. 2003. Interleukin-6 stimulates lipolysis and fat 
oxidation in humans. J. Clin. Endocrinol. Metab. 88: 3005-3010.

85. Van Stijn CMW, Kim J, Lusis AJ, ve ark. 2015. Macrophage polarization phenotype regulates adiponectin receptor expression and adiponectin anti-inflammatory response. FASEB J. 29: 636649.

86. Virtanen KA, Lidell ME, Orava J, ve ark. 2009 Functional brown adipose tissue in healthy adults. N. Engl. J. Med. 360: 1518-1525.

87. Voulgari C, Tentolouris N, Dilaveris P, ve ark. 2011. Increased heart failure risk in normalweight people with metabolic syndrome compared with metabolically healthy obese individuals. J. Am. Coll. Cardiol. 58: 13431350 .

88. Vozarova B, Weyer C, Hanson K, ve ark. 2001. Circulating interleukin- 6 in relation to adiposity, insulin action, and insulin secretion. Obes. Res. 9: 414-417.

89. Waki H, Yamauchi T, Kamon J, et al. 2003. Impaired multimerization of human adiponectin mutants associated with diabetes. Molecular structure and multimer formation of adiponectin. J. Biol. Chem. 278: 40352-40363.

90. Wang QA, Tao C, Gupta RK, ve ark. 2013.Tracking adipogenesis during white adipose tissue development, expansion and regeneration. Nat. Med. 19: 1338-1344.

91. Weisberg SP, McCann D, Desai M, ve ark. 2003. Obesity is associated with macrophage accumulation in adipose tissue. J. Clin. Invest. 112: 1796-1808.

92. Wensveen FM, Valentić S, Šestan M, ve ark. 2015. The "Big Bang" in obese fat: Events initiating obesity-induced adipose tissue inflammation. Eur. J. Immunol. 45: 2446-2456.
93. Wieckowska A, Papouchado BG, Li Z, ve ark. 2008. Increased hepatic and circulating interleukin-6 levels in human nonalcoholic steatohepatitis. Am. J. Gastroenterol. 103: 13721379 .

94. Winer S, Chan Y, Paltser G, ve ark. 2009. Normalization of obesity-associated insulin resistance through immunotherapy. Nat. Med. 15: 921-929.

95. Wu D, Molofsky AB, Liang H-E, ve ark. 2011. Eosinophils sustain adipose alternatively activated macrophages associated with glucose homeostasis. Science. 332: 243-247.

96. Xue Y, Petrovic N, Cao R, ve ark. 2009. Hypoxia-1ndependent angiogenesis in adipose tissues during cold acclimation. Cell Metab. 9: 99-109.

97. Yamauchi T, Kamon J, Ito Y, ve ark. 2003. Cloning of adiponectin receptors that mediate antidiabetic metabolic effects. Nature. 423: 762769.

98. Yang RZ, Lee MJ, Hu H, ve ark. 2006. Acutephase serum amyloid A: an inflammatory adipokine and potential link between obesity and its metabolic complications. PLoS Med. 3: e287.

99. Yeop Han C, Kargi AY, Omer M, ve ark. 2010. Differential effect of saturated and unsaturated free fatty acids on the generation of monocyte adhesion and chemotactic factors by adipocytes: Dissociation of adipocyte hypertrophy from inflammation. Diabetes. 59: 386-396.

100. Zhang Y, Proenca R, Maffei M, ve ark. 1994. Positional cloning of the mouse obese gene and its human homologue. Nature. 372: 425-432. 